\title{
Long-range atmospheric transport of volatile monocarboxylic acids with Asian dust over a high mountain snow site, central Japan
}

\author{
Tomoki Mochizuki $^{1, \mathrm{a}}$, Kimitaka Kawamura ${ }^{1, \mathrm{~b}}$, Kazuma Aoki ${ }^{2}$, and Nobuo Sugimoto ${ }^{3}$ \\ ${ }^{1}$ Institute of Low Temperature Science, Hokkaido University, N19 W8, Kita-ku Sapporo, 060-0819, Japan \\ ${ }^{2}$ Department of Earth Science, Faculty of Science, University of Toyama, 3190, Gofuku, Toyama 930-8555, Japan \\ ${ }^{3}$ National Institute of Environmental Studies, 16-2 Onogawa, Tsukuba, Ibaraki 305-8506, Japan \\ a now at: School of Food and Nutritional Sciences, University of Shizuoka, 52-1 Yada, Shizuoka 422-8526, Japan \\ b now at: Chubu Institute for Advanced Studies, Chubu University, 1200 Matsumoto-cho, Kasugai 487-8501, Japan \\ Correspondence to: Kimitaka Kawamura (kkawamura@isc.chubu.ac.jp)
}

Received: 14 July 2016 - Published in Atmos. Chem. Phys. Discuss.: 21 July 2016

Revised: 17 October 2016 - Accepted: 27 October 2016 - Published: 24 November 2016

\begin{abstract}
To understand the long-range transport of monocarboxylic acids from the Asian continent to the Japanese islands, we collected snowpack samples from a pit sequence (depth ca. $6 \mathrm{~m}$ ) at the Murodo-Daira snowfield near the summit of Mt. Tateyama, central Japan, in 2009 and 2011. Snow samples $(n=16)$ were analyzed for normal $\left(\mathrm{C}_{1}-\mathrm{C}_{10}\right)$, branched chain $\left(\mathrm{iC}_{4}-\mathrm{iC}_{6}\right)$, aromatic (benzoic and toluic acid isomers), and hydroxyl (glycolic and lactic) monocarboxylic acids, together with inorganic ions and dissolved organic carbon (DOC). Acetic acid $\left(\mathrm{C}_{2}\right)$ was found to be a dominant species (average $125 \mathrm{ng} \mathrm{g}^{-1}$ ), followed by formic acid $\left(\mathrm{C}_{1}\right)\left(85.7 \mathrm{ng} \mathrm{g}^{-1}\right)$ and isopentanoic acid $\left(\mathrm{iC}_{5}\right)\left(20.0 \mathrm{ng} \mathrm{g}^{-1}\right)$. We found a strong correlation $(r=0.88)$ between formic plus acetic acids and non-sea-salt $\mathrm{Ca}^{2+}$ that is a proxy of Asian dust. Contributions of total monocarboxylic acids to DOC in $2009(21.2 \pm 11.6 \%)$ were higher than that in 2011 $(3.75 \pm 2.62 \%)$, being consistent with higher intensity of Asian dust in 2009 than in 2011. Formic plus acetic acids also showed a positive correlation $(r=0.90)$ with benzoic acid that is a tracer of automobile exhaust, indicating that monocarboxylic acids and their precursors are largely emitted from anthropogenic sources in China and/or secondarily produced in the atmosphere by photochemical processing. In addition, the ratio of formic plus acetic acids to nss- $-\mathrm{Ca}^{2+}$ (0.27) was significantly higher than those $(0.00036-0.0018)$ obtained for reference dust materials of Chinese loess deposits from the Tengger and Gobi deserts. This result suggests that volatile and semi-volatile organic acids are adsorbed on the alkaline dust particles during long-range atmo-
\end{abstract}

spheric transport. Entrainment of organic acids by dusts is supported by a good correlation $(r=0.87)$ between formic plus acetic acids and $\mathrm{pH}$ of melt snow samples. Our study suggests that Asian alkaline dusts may be a carrier of volatile monocarboxylic acids.

\section{Introduction}

Low molecular weight (LMW) monocarboxylic acids such as formic $(\mathrm{HCOOH})$ and acetic $\left(\mathrm{CH}_{3} \mathrm{COOH}\right)$ acids are present in the atmosphere as major gaseous and particulate organic components (e.g., Kawamura and Kaplan, 1984; Kawamura et al., 2000; Paulot et al., 2011). Gaseous and particulate formic and acetic acids have been reported in urban (Kawamura et al., 2000), forest (Andreae et al., 1988), high mountain (Preunkert et al., 2007), marine (Miyazaki et al., 2014), and Arctic samples (Legrand et al., 2004). Salts of organic acids in aerosols are water-soluble and thus influence the radiation budget of the earth's atmosphere by acting as cloud condensation nuclei (CCN) (Kanakidou et al., 2005). In addition, LMW monocarboxylic acids have been detected in wet deposition such as rain, cloud and fog water, and snow samples (Maupetit and Delmas, 1994; Keene et al., 1995; Kawamura et al., 1996, 2012). Thus, organic acids are scavenged by wet deposition from the upper troposphere. It is also important to note that organic acids largely contribute to total acidity of rainwaters (Kawamura et al., 1996; Keene et al., 1983). 
Formic and acetic acids have a variety of sources such as primary emission from motor exhausts (Kawamura et al., 2000) and vegetation (Kesselmeier et al., 1998), and secondary formation via the oxidation of anthropogenic and biogenic precursors such as toluene (laboratory data in Kawamura) and isoprene (Paulot et al., 2011). Kawamura et al. (2000) reported that photochemical oxidations of various organic precursors are more important as a source of monocarboxylic acids in the troposphere. On the other hand, microorganisms are known to produce branched chain $\left(\mathrm{iC}_{4}\right.$ and $\mathrm{iC}_{5}$ ) monocarboxylic acids (Allison, 1978).

The Japanese islands are located in the western North Pacific Rim, which is influenced by the Asian outflow of dusts and air pollutants. Asian dust (Kosa) events in the desert areas of North China promote the delivery of air pollutants with dust particles to the western North Pacific by westerly winds (e.g., Iwasaka et al., 1983). LMW monocarboxylic acids have been detected in alpine snow samples collected near the summit of Mt. Tateyama (Kawamura et al., 2012). They reported higher concentrations of monocarboxylic acids in snow pit samples with dust layers, suggesting that monocarboxylic acids may be associated with Asian dust during longrange atmospheric transport.

During the winter monsoon season, the Japanese high mountains facing the Sea of Japan are known to have heavy snowfall, which is associated with a significant evaporation of water vapors from the warm Tsushima Current in the Sea of Japan under a strong westerly wind condition. Alpine mountain snow sequences would provide useful information on the chemical states of Asian dust deposited over the snowfield, in which atmospheric organic acids are well preserved in snow layers (Osada et al., 2004).

In the present study, we collected snowpack samples from a pit sequence in the Murodo-Daira snowfield (ca. $6 \mathrm{~m}$ in depth) near the summit of Mt. Tateyama, central Japan, in April of 2009 and 2011. To better understand the sources of monocarboxylic acid and their long-range transport by Asian dust over the Japanese islands, 16 snowpack samples were analyzed for monocarboxylic acids, inorganic ions, and dissolved organic carbon (DOC) as well as reference dust materials of Chinese loess deposit samples collected from the Tengger and Gobi deserts. We discuss the contributions of LMW monocarboxylic acids to DOC as well as the association of monocarboxylic acids with alkaline dust particles during long-range atmospheric transport. Relations between monocarboxylic acids and $\mathrm{pH}$ values of the snowmelt water will also be discussed in terms of atmospheric titration of alkaline dust particles by acidic species, including organic acids during atmospheric transport.

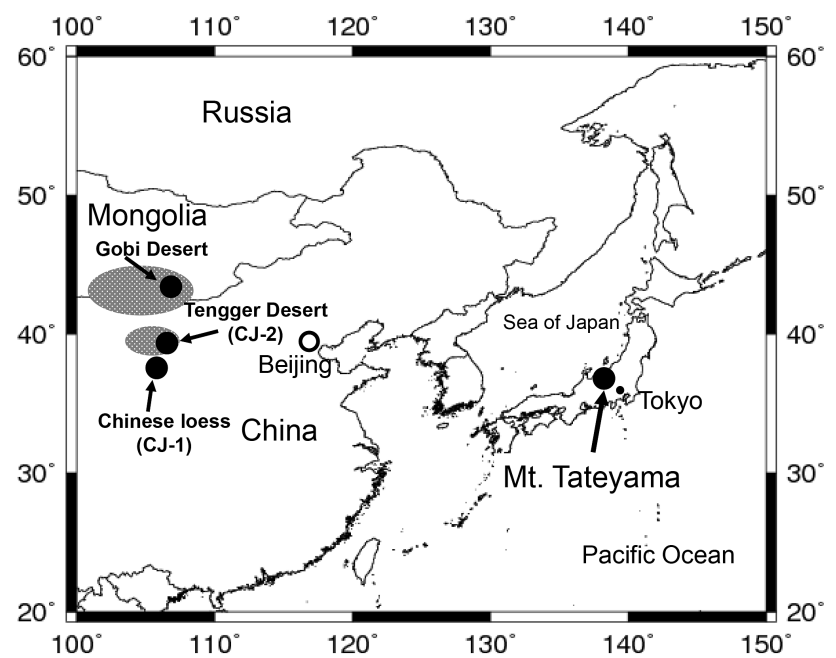

Figure 1. Location of the snowpack sampling site (Murodo-Daira) near Mt. Tateyama, central Japan. Sites are also shown for the loess deposit reference samples, which were collected from the Tengger and Gobi deserts in China and Mongolia (Nishikawa et al., 2000, 2013).

\section{Material and methods}

\subsection{Sample collection}

The details on the snow collection and sample storage methods were described in Kawamura et al. (2012) and Mochizuki et al. (2016). Snowpack samples were collected at the Murodo-Daira site $\left(36.58^{\circ} \mathrm{N}, 137.36^{\circ} \mathrm{E}\right.$; elevation $\left.2450 \mathrm{~m}\right)$ near Mt. Tateyama (elevation 3015 m), central Japan (Fig. 1). A snow pit hole (depth, ca. $6 \mathrm{~m}$ ) was dug down to the ground. Table 1 provides descriptions of snow samples collected from the snow pit sequence, in which several brown-colored dirty layers were recognized by visual observation. Five snowpack samples including three dirty layers were collected from the pit sequence on 18 April 2009. Eleven snowpack samples including four dirty layers were collected from the pit sequence on 17 April 2011. In order to evaluate the consistent distributions of snow samples within the same snow horizon with dirty layers, another snowpack sample (no. $4^{\prime}$ ) was collected at ca. $1 \mathrm{~m}$ away from the location of sample no. 4. Because the thickness of dirty layers in the snow pit sequence is ca. $10 \mathrm{~cm}$ or more, brown-colored particles are deposited together with snowflakes during snow precipitation rather than dry deposition.

The snow samples were placed in a pre-cleaned glass jar (8L) using a clean stainless steel scoop. To avoid microbial degradation of organic compounds, mercuric chloride $\left(\mathrm{HgCl}_{2}\right)$ was added to the glass jar prior to collecting the snow sample. The sample jars were sealed with a Teflonlined screw cap and transported to the laboratory in Sapporo within 4 days by a commercial refrigerated transport service, which kept the samples in darkness at ca. $5^{\circ} \mathrm{C}$ and 
Table 1. Descriptions of snowpack samples collected from a pit at Murodo-Daira near Mt. Tateyama, Japan, in 2009 and 2011. Snowpack sample no. $4^{\prime}$ was collected from different snow pit sequences parallel to sample no. $4^{\prime}$. Bold letters represent dust layers.

\begin{tabular}{|c|c|c|c|}
\hline Year & Sample ID & Snow depth $(\mathrm{cm})$ & Description \\
\hline \multirow[t]{9}{*}{$2008-2009$} & No. 1 & 325-335 & Weak dust layer \\
\hline & & & $\begin{array}{l}\text { Asian dust events were observed on } 2 \text { February } 2009 \text { by a } \\
\text { lidar over Toyama. Air masses are derived from the Takla- } \\
\text { makan and Gobi deserts. }\end{array}$ \\
\hline & No. 2 & $410-420$ & Clean snow layer \\
\hline & No. 3 & 425-435 & Dusty snow layer \\
\hline & & & $\begin{array}{l}\text { Asian dust events were observed on } 1 \text { January } 2009 \text { by a } \\
\text { lidar over Toyama. Air masses are derived from the Takla- } \\
\text { makan and Gobi deserts. }\end{array}$ \\
\hline & No. 4 & $520-530$ & Dusty snow layer \\
\hline & & & $\begin{array}{l}\text { Asian dust events were observed on } 10 \text { December } 2008 \text { by a } \\
\text { lidar over Toyama. Air masses are derived from the Takla- } \\
\text { makan and Gobi deserts. }\end{array}$ \\
\hline & No. 4' & $520-530$ & Dusty snow layer \\
\hline & No. 5 & $530-540$ & Granular snow \\
\hline \multirow[t]{15}{*}{ 2010-2011 } & No. 6 & $115-125$ & Granular snow with ice plate \\
\hline & No. 7 & 169-178 & Dusty and granular snow \\
\hline & & & $\begin{array}{l}\text { Asian dust events were observed on 22-24 February } 2011 \\
\text { by a lidar over Toyama. Air masses are derived from the } \\
\text { Taklamakan and Gobi deserts. }\end{array}$ \\
\hline & No. 8 & $290-300$ & Compacted snow layer \\
\hline & No. 9 & $390-400$ & Compacted snow layer \\
\hline & No. 10 & $400-410$ & Dusty and compacted snow \\
\hline & & & $\begin{array}{l}\text { Asian dust events were observed on } 31 \text { December } 2010 \text { by a } \\
\text { lidar over Toyama. Air masses are derived from the Takla- } \\
\text { makan and Gobi deserts. }\end{array}$ \\
\hline & No. 11 & $430-440$ & Compacted snow layer \\
\hline & No. 12 & $460-466$ & Dusty and compacted snow \\
\hline & & & $\begin{array}{l}\text { Asian dust events were observed on } 25-26 \text { December } 2010 \\
\text { by a lidar over Toyama. Air masses are derived from the } \\
\text { Taklamakan and Gobi deserts. }\end{array}$ \\
\hline & No. 13 & $507-527$ & Compacted snow with ice plate \\
\hline & No. 14 & $542-548$ & Dusty and compacted snow \\
\hline & & & $\begin{array}{l}\text { Asian dust events were observed on } 6 \text { December } 2010 \text { by a } \\
\text { lidar over Toyama. Air masses are derived from the Takla- } \\
\text { makan and Gobi deserts. }\end{array}$ \\
\hline & No. 15 & $590-605$ & Granular and compacted snow \\
\hline & No. 16 & $630-635$ & Granular snow \\
\hline
\end{tabular}

constant humidity. The samples were stored in a dark refrigerator room at $4{ }^{\circ} \mathrm{C}$ prior to analysis.

We also analyzed the reference dust materials (Kosa) including Chinese loess deposits from the Tengger (CJ-1, $<250 \mu \mathrm{m}$ and $\mathrm{CJ}-2,<100 \mu \mathrm{m}$ ) and Gobi deserts (Gobi, $<10 \mu \mathrm{m})$. The reference materials were purchased from the National Institute for Environmental Studies, for the measurements of LMW monocarboxylic acids, inorganic ions, and DOC. Reference dust samples $(0.1 \mathrm{~g})$ were extracted with ultra-pure water by the methods as described below. The detailed information of reference samples is reported elsewhere (Nishikawa et al., 2000, 2013).

\subsection{Chemical analysis}

Monocarboxylic acids were determined as p-bromophenacyl esters using the capillary gas chromatography (GC) and GCmass spectrometry (GC-MS) methods (Kawamura and Kaplan, 1984); $150 \mathrm{~mL}$ of melted snow samples were transferred to a pear-shaped glass flask $(300 \mathrm{~mL})$. To avoid the evaporative loss of volatile monocarboxylic acids from samples during analytical procedure, $\mathrm{pH}$ was adjusted to 8.5-9.0 by adding several drops of $0.05 \mathrm{M} \mathrm{KOH}$ solution to form organic acid salts (e.g., $\mathrm{CH}_{3} \mathrm{COO}^{-} \mathrm{K}^{+}$). The sample was concentrated down to $10 \mathrm{~mL}$ using a rotary evaporator under vacuum $(20 \mathrm{~mm} \mathrm{Hg})$ at $50{ }^{\circ} \mathrm{C}$. The concentrates were fil- 
tered through quartz wool packed in a Pasteur pipette. The filtrates were concentrated down to $0.5 \mathrm{~mL}$. To convert all organic acids to $\mathrm{RCOO}^{-} \mathrm{K}^{+}$form, the concentrates were passed through a glass column (Pasteur pipette) packed with cation exchange resin (DOWEX 50W-X4, 100-200 meshes, $\mathrm{K}^{+}$form). Organic acids were eluted with pure water and transferred in a $25 \mathrm{~mL}$ pear-shaped flask. The $\mathrm{pH}$ of the sample was checked to be 8.5-9.0 and then dried using a rotary evaporator under vacuum $(20 \mathrm{~mm} \mathrm{Hg})$, followed by blowdown with pure nitrogen gas for $30 \mathrm{~s}$. The former process generally requires $15-20 \mathrm{~min}$.

Acetonitrile $(4 \mathrm{~mL})$ was added to the dried sample, and $\mathrm{RCOO}^{-} \mathrm{K}^{+}$salts were reacted with $\alpha$, pdibromoacetophenone $(0.1 \mathrm{M}, 50 \mu \mathrm{L})$ as a derivatization reagent and dicyclohexyl-18-crown-6 $(0.01 \mathrm{M}, 50 \mu \mathrm{L})$ as a catalyst to derive p-bromophenacyl esters at $80^{\circ} \mathrm{C}$ for $2 \mathrm{~h}$. The reaction mixture was dried using a rotary evaporator under vacuum at $30^{\circ} \mathrm{C}$. The derived esters were dissolved in $0.5 \mathrm{~mL}$ of $\mathrm{n}$-hexane/dichloromethane $(2: 1)$ mixture and then purified on a silica gel column (Pasteur pipette). Excess reagent was eluted with $\mathrm{n}$-hexane/dichloromethane $(2: 1)$ mixture $(7 \mathrm{~mL})$ and then p-bromophenacyl esters were eluted with dichloromethane/methanol $(95: 5)$ mixture $(2 \mathrm{~mL})$ into a glass vial $(2 \mathrm{~mL})$. The esters were dried by blow-down using pure nitrogen gas and then dissolved in n-hexane $(100 \mu \mathrm{L})$. In addition, the esters of hydroxyacids (lactic and glycolic acids) were reacted with N,O-bis-(trimethylsilyl) trifluoroacetamide (BSTFA) with $1 \%$ trimethylsilyl chloride and $10 \mu \mathrm{L}$ of pyridine to derive trimethylsilyl (TMS) ethers for the hydroxyl $(\mathrm{OH})$ group at $70^{\circ} \mathrm{C}$ for $3 \mathrm{~h}$.

p-Bromophenacyl esters and their TMS ethers were determined using a capillary gas chromatograph (HP GC6890, Hewlett-Packard, USA) equipped with a flame ionization detector. The esters were separated using a fused silica capillary column (HP-5, $30 \mathrm{~m} \times 0.2 \mathrm{~mm}$ i.d., film thickness $0.5 \mu \mathrm{m}$ ). The derivatives were also analyzed by GC-MS (Agilent GC7890A and 5975C MSD, Agilent, USA). The compounds were identified by comparing GC retention time and mass spectra of authentic standards. Details of analytical procedure were described previously (Kawamura et al., 2012), except for the $\mathrm{pH}$ adjustment with $\mathrm{KOH}$ solution. We tested the recoveries of authentic monocarboxylic acid standards $\left(\mathrm{C}_{1-}-\right.$ $\mathrm{C}_{10}, \mathrm{iC}_{4}-\mathrm{iC}_{6}$, benzoic, toluic, lactic, and glycolic acids) that were spiked into ultra-pure water. The results showed that the recoveries of organic acids were better than $80 \%$. Analytical errors in the GC/FID analysis using authentic standards were within $2 \%$. Total relative standard deviations based on triplicate analysis of real samples were within $12 \%$. Detection limits of organic acids were estimated to be $0.001-$ $0.004 \mathrm{ng} \mathrm{g}^{-1}$.

To measure inorganic ions, samples were passed through a membrane disk filter $(0.22 \mu \mathrm{m}$, Millipore Millex-GV, Merck, USA) and the filtrates were injected into an ion chromatograph (Model 761 compact IC, Metrohm, Switzerland) equipped with an AS-09 autosampler (Kawamura et al.,
2012). Anion analysis was conducted using a Shodex SI-90 $4 \mathrm{E}$ column and a $1.8 \mathrm{mM} \mathrm{Na} 2 \mathrm{CO}_{3}+1.7 \mathrm{mM} \mathrm{NaHCO} \mathrm{N}_{3}$ solution as eluent. Cation analysis was conducted using a $\mathrm{C} 2$ 150 column and a $4.0 \mathrm{mM}$ tartaric acid $+1.0 \mathrm{mM}$ dipicolinic acid solution as eluent. The total analytical precision is $4 \%$ (Miyazaki et al., 2010).

After removing the particles in the samples on a disk filter $(0.22 \mu \mathrm{m}$, Millipore Millex-GV, Merck, USA), DOC was determined using a total organic carbon (TOC) analyzer (Model TOC-Vcsh, Shimadzu) (Miyazaki et al., 2011).

\subsection{Non-sea-salt ions}

Concentrations of non-sea-salt ionic species $X\left(M_{\mathrm{nss}-x}\right)$ were estimated by the following equation:

$M_{\mathrm{nss}-x}=M_{x}-(X / \mathrm{Na})_{\mathrm{sw}} M_{\mathrm{Na}}$,

where $M_{x}$ and $M_{\mathrm{Na}}$ are the concentrations of $X$ and of $\mathrm{Na}$, respectively. $(X / \mathrm{Na})_{\text {sw }}$ means the mass ratio of species $X$ to $\mathrm{Na}$ in seawater (Duce et al., 1983). The ratios are 0.25 $\left(\mathrm{SO}_{4}^{2-}\right), 0.037\left(\mathrm{~K}^{+}\right), 0.038\left(\mathrm{Ca}^{2+}\right)$, and $0.12\left(\mathrm{Mg}^{2+}\right)$ (Berg and Winchester, 1978). The ratio of $\mathrm{F}^{-}$is 0.000146 (Yang et al., 2009).

\subsection{Lidar observation and back trajectory analysis}

We detected Asian dust events by the lidar observation (data are provided by the National Institute for Environmental Studies) over Imizu $\left(36.70^{\circ} \mathrm{N}, 137.10^{\circ} \mathrm{E}\right)$, ca. $40 \mathrm{~km}$ northwest of Mt. Tateyama, Toyama Prefecture, Japan, during December to March in each year. The observation wavelength of the laser is $532 \mathrm{~nm}$. Details of the extinction coefficient of dust particles were given in Shimizu et al. (2004). One example of a lidar image is presented in Fig. 2. Dense dust layers were recorded at the upper layers $(3-4 \mathrm{~km})$ over Imizu on 10 December 2008, whose dust event should be recorded in the snow pit sequences collected in 2009 (possibly corresponds to no. 4; see Table 1). This dust event was also recognized by the lidar observations at Niigata, Sendai, and Tsukuba in Japan. We estimated that Asian dust events observed on 10 December, 1 January, and 2 February during 2008-2009 and 6, 25-26 and 31 December, and 22-24 February during 2010-2011 correspond to sample ID nos. 4, 3, 1, no. 14, 12, 10 , and 7 , respectively (Table 1 ).

To investigate the source of air masses during the snow season (November to April), 7-day backward air mass trajectories were calculated at a level of $3000 \mathrm{~m}$ a.s.1. using an online program, Meteorological Data Explorer (METEX), which was developed by the National Institute for Environmental Studies (NIES), Japan. Meteorological data were obtained from the National Centers for Environmental Prediction (NCEP) Reanalysis data. Figure 3 shows the back air mass trajectories corresponding to selected dust layers (Table 1). The heights of air masses over the Asian continent and the Sea of Japan ranged from 2500 to $6000 \mathrm{~m}$. 


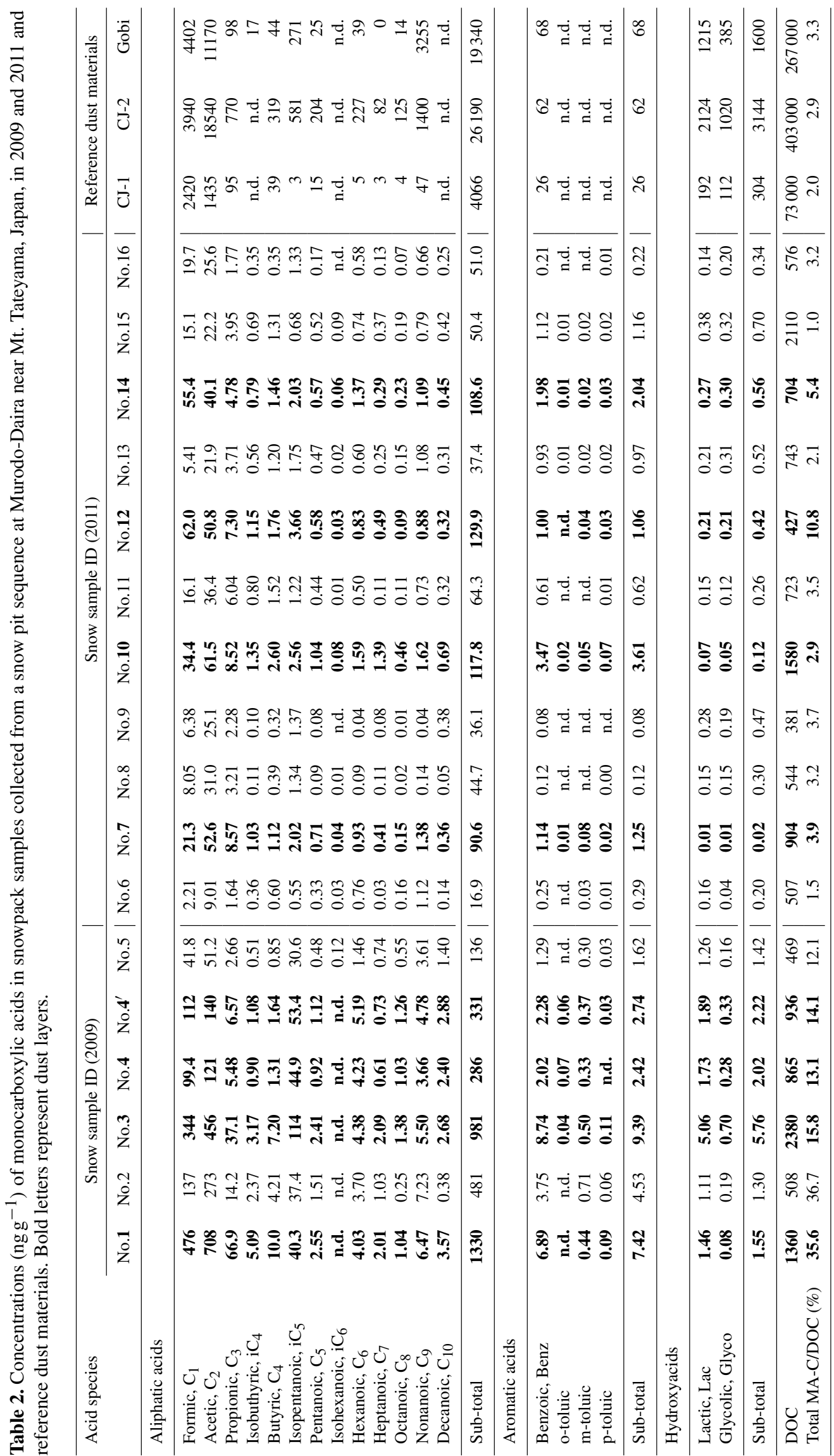




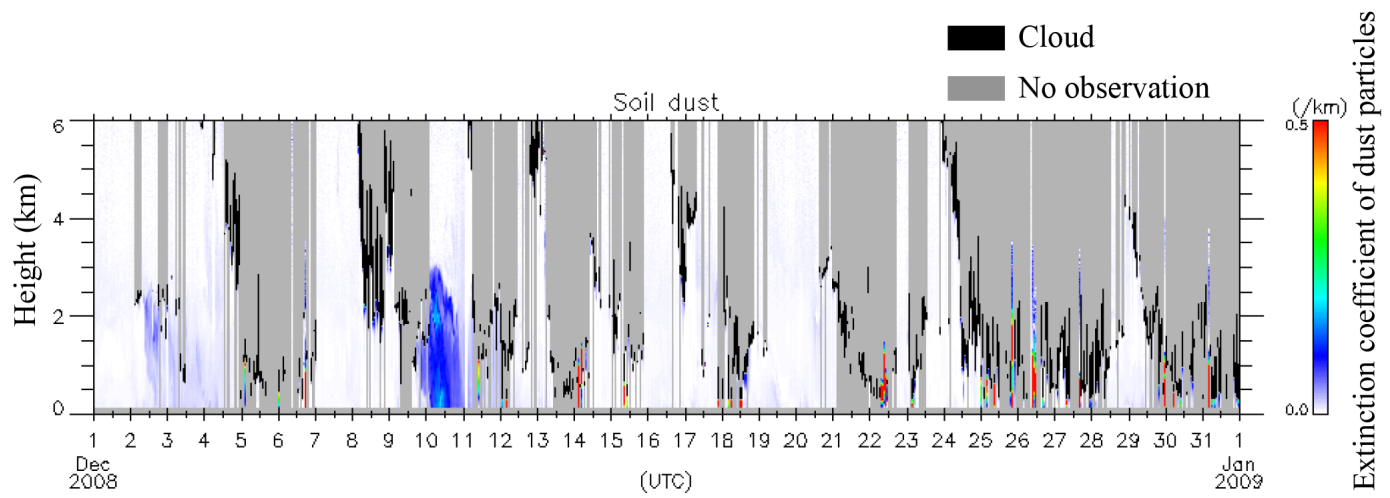

Figure 2. Example of lidar measurements of dusts obtained at Imizu, Toyama (ca. $40 \mathrm{~km}$ northwest of Mt. Tateyama) during 1-31 December 2008. The color scale indicates the extinction coefficient of dust particles based on lidar measurements. Black line represents clouds and gray shade above the black lines represents no data.

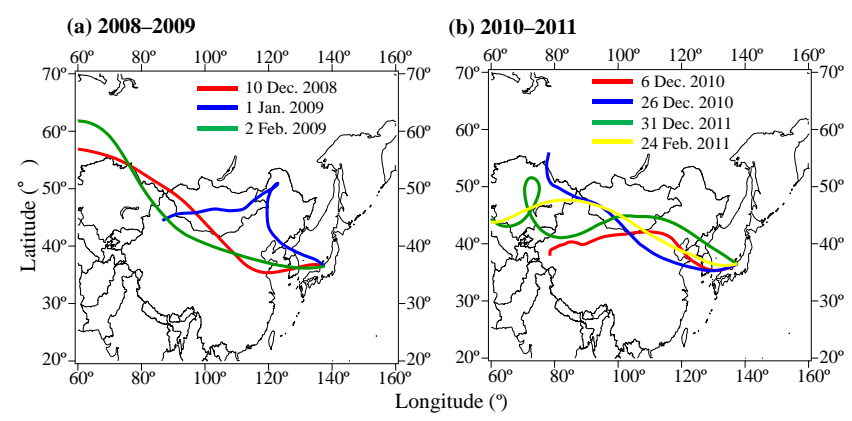

Figure 3. Seven-day airmass back trajectories at a level of $3000 \mathrm{~m}$ a.s.l. over the Murodo-Daira site in (a) 2008-2009 and (b) 2010-2011. Color lines show the trajectories associated with dust layers as observed by a lidar.

\section{Results}

\subsection{Tateyama snow pit samples}

Homologous series of low molecular weight normal aliphatic $\left(\mathrm{C}_{1}-\mathrm{C}_{10}\right)$, branched chain $\left(\mathrm{iC}_{4}-\mathrm{iC}_{6}\right)$, hydroxy (lactic and glycolic), and aromatic (benzoic acid and o-, m-, and ptoluic acid isomers) monocarboxylic acids were detected in the snow pit samples (Table 2). We found that differences in the concentrations of each monocarboxylic acid between sample nos. 4 and $4^{\prime}$ are comparable to the total relative standard deviations based on triplicate analysis of real samples. Thus, we consider that each horizontal layer in the snow pit site is homogenous and that each snow sample is representative of the snowfall events over the Murodo site.

Acetic acid $\left(\mathrm{C}_{2}\right)$ was found to be the dominant species (2009: 51.2-708 $\mathrm{ng} \mathrm{g}^{-1} ; 2011:$ 9.01-61.5 $\mathrm{ng} \mathrm{g}^{-1}$ ), followed by formic acid $\left(\mathrm{C}_{1}\right)$ (2009: $41.8-476 \mathrm{ng} \mathrm{g}^{-1}$; 2011: 2.21$\left.62.0 \mathrm{ng} \mathrm{g}^{-1}\right)$. Concentrations of $\mathrm{C}_{3}-\mathrm{C}_{10}$ acids were $1-2$ orders of magnitude lower than $\mathrm{C}_{2}$. In contrast, $\mathrm{iC}_{5}$ acid (2009: 30.6-114 $\mathrm{ng} \mathrm{g}^{-1} ; 2011$ : $0.55-3.66 \mathrm{ng} \mathrm{g}^{-1}$ ) was detected as

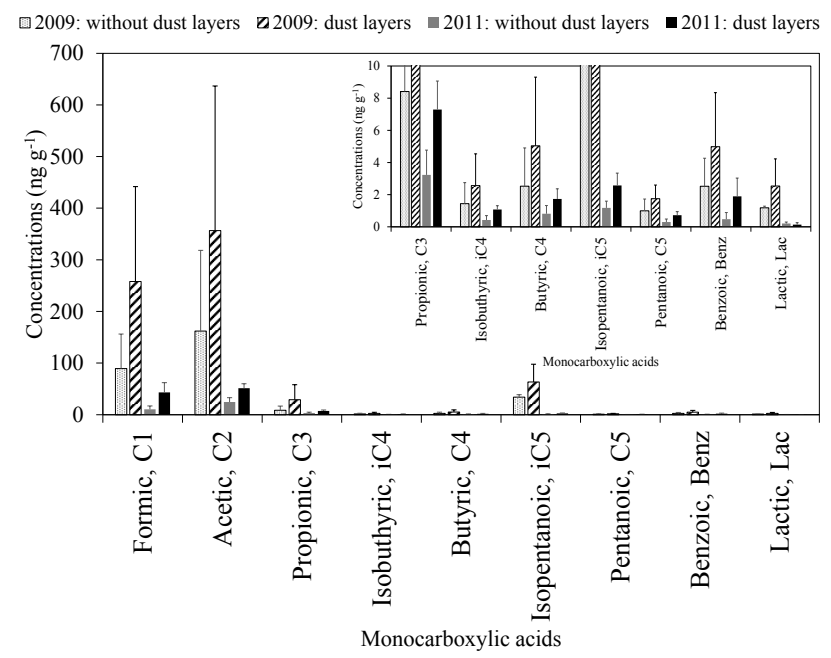

Figure 4. Concentrations of selected low molecular weight monocarboxylic acids in Mt. Tateyama snow samples.

the most abundant branched chain acid. Lactic and glycolic acids were also detected as hydroxyacids in the snow pit samples. Concentrations of lactic and glycolic acids are 1 and 2 orders of magnitude lower than those of major monocarboxylic acids $\left(\mathrm{C}_{1}\right.$ and $\left.\mathrm{C}_{2}\right)$, respectively. The concentration of benzoic acid ranged from 0.08 to $8.74 \mathrm{ng} \mathrm{g}^{-1}$. Total concentrations of toluic acid isomers were found to be significantly lower (average $0.07 \mathrm{ng} \mathrm{g}^{-1}$ ) than that of benzoic acid $\left(2.11 \mathrm{ng} \mathrm{g}^{-1}\right)$. Average concentrations of total monocarboxylic acids in the dust layers (2009: $739 \mathrm{ng} \mathrm{g}^{-1} ; 2011$ : $114 \mathrm{ng} \mathrm{g}^{-1}$ ) were greater than those without dust layers (2009: $313 \mathrm{ng} \mathrm{g}^{-1} ; 2011: 43 \mathrm{ng} \mathrm{g}^{-1}$ ) (Fig. 4). Concentrations of DOC ranged from 469 to $2380 \mathrm{ng} \mathrm{g}^{-1}$ in 2009 and 381 to $2110 \mathrm{ng} \mathrm{g}^{-1}$ in 2011 (Table 2). The highest concentration of DOC $\left(2380 \mathrm{ng} \mathrm{g}^{-1}\right)$ was found in sample no. 3 , in which a dust layer was observed. 


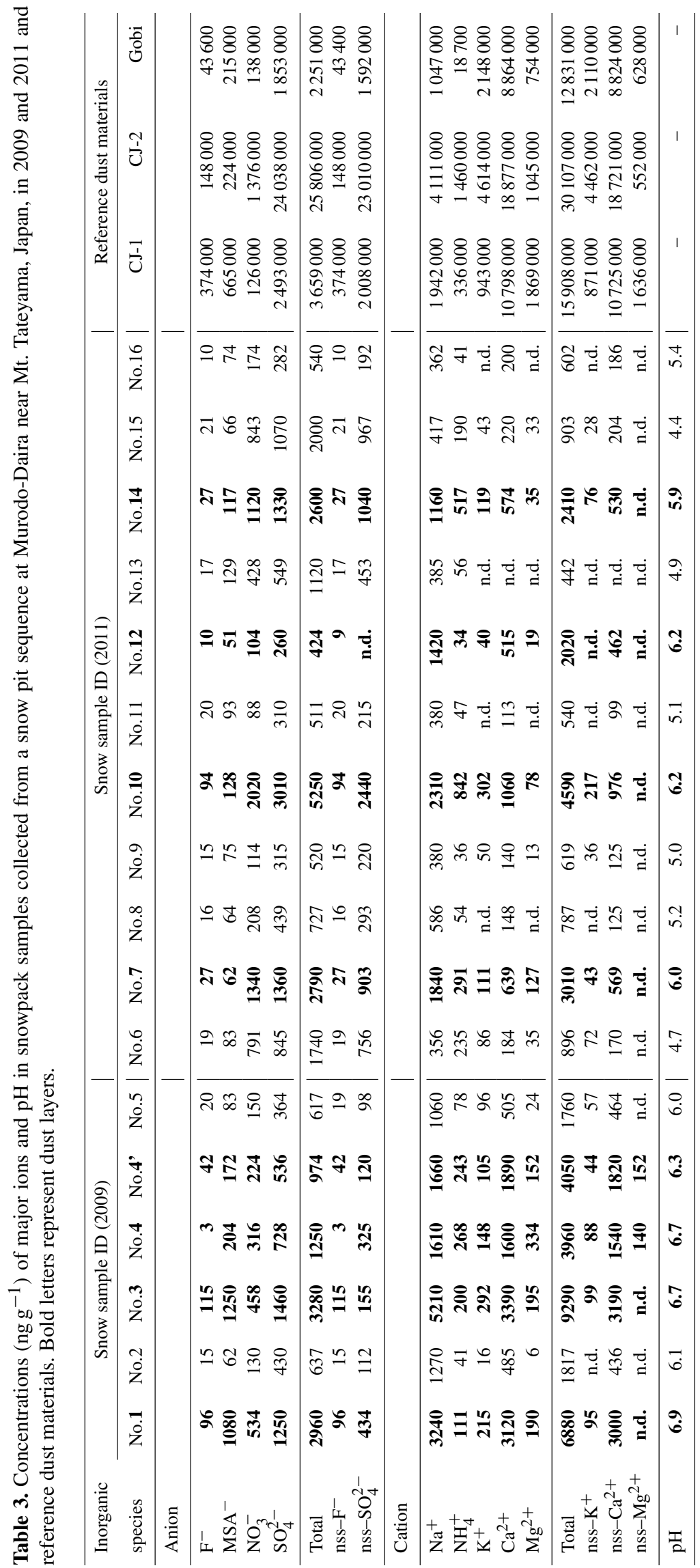


We detected cations $\left(\mathrm{Ca}^{2+}, \mathrm{Na}^{+}, \mathrm{Mg}^{2+}, \mathrm{K}^{+}\right.$, and $\left.\mathrm{NH}_{4}^{+}\right)$ and anions $\left(\mathrm{F}^{-}, \mathrm{NO}_{3}^{-}, \mathrm{SO}_{4}^{2-}\right.$, and $\left.\mathrm{MSA}^{-}\right)$in snow pit samples collected in both 2009 and 2011 from the Murodo-Daira site near Mt. Tateyama (Table 3). Concentrations of nss$\mathrm{Ca}^{2+}, \mathrm{nss}-\mathrm{Mg}^{2+}$, nss- $\mathrm{K}^{+}$, nss- $\mathrm{F}^{-}$, and nss- $\mathrm{SO}_{4}^{2-}$ were calculated as shown in Table 3. $\mathrm{NO}_{3}^{-}$and nss- $\mathrm{SO}_{4}^{2-}$ are two major anions. The highest concentrations of $\mathrm{NO}_{3}^{-}\left(2020 \mathrm{ng} \mathrm{g}^{-1}\right)$ and nss- $\mathrm{SO}_{4}^{2-}\left(2440 \mathrm{ng} \mathrm{g}^{-1}\right)$ were obtained in sample no. 10 , in which a dust layer was observed. On the other hand, $\mathrm{Na}^{+}$and nss-Ca ${ }^{2+}$ are two major cations. Higher concentrations of $\mathrm{Na}^{+}$and nss- $-\mathrm{Ca}^{2+}$ were found in sample nos. $1\left(\mathrm{Na}^{+}: 3240 \mathrm{ng} \mathrm{g}^{-1}\right.$; $\left.\mathrm{nss}-\mathrm{Ca}^{2+}: 3000 \mathrm{ng} \mathrm{g}^{-1}\right)$ and $3\left(\mathrm{Na}^{+}\right.$: $5210 \mathrm{ng} \mathrm{g}^{-1}$; nss- $-\mathrm{Ca}^{2+}: 3190 \mathrm{ng} \mathrm{g}^{-1}$ ), both of which showed the presence of a dust layer. The $\mathrm{pH}$ of melt snow samples ranged from 4.4 to 6.9 (Table 3). Higher $\mathrm{pH}$ was found in sample nos. 1,3 , and $4(\mathrm{pH}=6.7-6.9)$, in which dust layers were observed.

Average concentrations of $\mathrm{C}_{1}\left(202 \pm 170 \mathrm{ng} \mathrm{g}^{-1}\right), \mathrm{C}_{2}$ $\left(292 \pm 249 \mathrm{ng} \mathrm{g}^{-1}\right)$, and $\mathrm{iC}_{5}\left(53.5 \pm 30.8 \mathrm{ngg}^{-1}\right)$ in 2009 are 1 order of magnitude higher than those in $2011\left(\mathrm{C}_{1}\right.$ : $22.4 \pm 20.1 \mathrm{ng} \mathrm{g}^{-1} ; \mathrm{C}_{2}: 34.2 \pm 15.8 \mathrm{ng} \mathrm{g}^{-1} ; \mathrm{iC}_{5}: 1.69 \pm$ $0.88 \mathrm{ng} \mathrm{g}^{-1}$ ). Similar tends were found for the average concentrations of minor monocarboxylic acids $\left(\mathrm{C}_{3}-\mathrm{C}_{10}, \mathrm{iC}_{4}\right.$, and $\mathrm{iC}_{6}$ ) in the snow pit samples in 2009 and 2011 . The average concentration of DOC in $2009\left(1090 \pm 712 \mathrm{ng} \mathrm{g}^{-1}\right)$ is slightly higher than that in $2011\left(836 \pm 534 \mathrm{ng} \mathrm{g}^{-1}\right)$. The contribution of total monocarboxylic acids to DOC (total MCAC / DOC) in $2009(21.2 \pm 11.6 \%)$ is 6 times higher than that in $2011(3.75 \pm 2.62 \%)$.

Average concentrations of $\mathrm{NO}_{3}^{-}\left(657 \pm 633 \mathrm{ng} \mathrm{g}^{-1}\right)$ and nss- $\mathrm{SO}_{4}^{2-}\left(748 \pm 682 \mathrm{ng} \mathrm{g}^{-1}\right)$ in 2011 are $2-3$ times higher than those in $2009\left(\mathrm{NO}_{3}^{-}: 302 \pm 166 \mathrm{ng} \mathrm{g}^{-1}\right.$; nss- $\mathrm{SO}_{4}^{2-}$ : $\left.207 \pm 139 \mathrm{ng} \mathrm{g}^{-1}\right)$. In contrast, average concentrations of nss$\mathrm{Ca}^{2+}$ in $2009\left(1740 \pm 1190 \mathrm{ng} \mathrm{g}^{-1}\right)$ are 5 times higher than those in $2011\left(345 \pm 285 \mathrm{ng} \mathrm{g}^{-1}\right)$.

\subsection{Reference dust materials}

We detected LMW monocarboxylic acids, inorganic ions, and DOC in the water extracts from three reference dust materials (CJ-1, CJ-2, and Gobi) (Tables 2 and 3). Concentrations of total LMW monocarboxylic acids in the reference dusts were $4370 \mathrm{ng} \mathrm{g}^{-1}$ (CJ-1), $29390 \mathrm{ng} \mathrm{g}^{-1}$ (CJ-2), and $21010 \mathrm{ng} \mathrm{g}^{-1}$ (Gobi). The dominant LMW monocarboxylic acids were formic and acetic acids. Concentrations of DOC were $73000 \mathrm{ng} \mathrm{g}^{-1}$ (CJ-1), $403000 \mathrm{ng} \mathrm{g}^{-1}$ (CJ-2), and $267000 \mathrm{ng} \mathrm{g}^{-1}$ (Gobi). Total MCA-C/DOC ratios in reference dust materials were $2.0 \%$ (CJ-1), $2.9 \%$ (CJ-2), and $3.3 \%$ (Gobi). Concentrations of nss- $\mathrm{Ca}^{2+}$ in the reference dust materials were $10700 \mathrm{\mu g} \mathrm{g}^{-1}$ (CJ-1), $18700 \mu \mathrm{g} \mathrm{g}^{-1}$ (CJ2), and $8820 \mu \mathrm{g} \mathrm{g}^{-1}$ (Gobi).

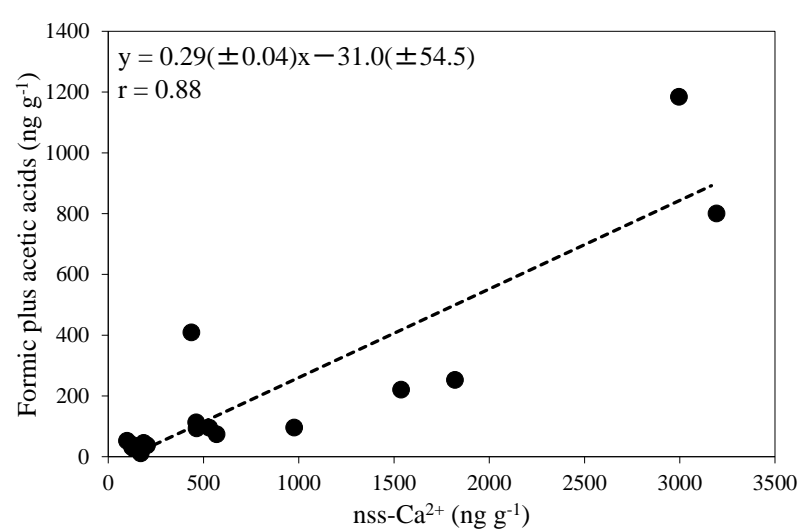

Figure 5. Scatter plot of concentrations of formic plus acetic acids vs. nss $-\mathrm{Ca}^{2+}$ in Mt. Tateyama snow samples. The dotted line represents the Deming linear regression.

\section{Discussion}

\subsection{Influence of Asian dust}

High concentrations of nss- $\mathrm{Ca}^{2+}$ were obtained in the dust layers of both 2009 and $2011 . \mathrm{Ca}^{2+}$ is known as a major metal ion to be transported from arid regions in North Asia with Asian dust (Mori et al., 2002; Tsai and Chen, 2006). In this study, contributions of nss- $\mathrm{Ca}^{2+}$ to $\mathrm{Ca}^{2+}$ in 2009 and 2011 are 95 and $91 \%$, respectively. In addition, the mass concentration ratios of $\mathrm{Mg} / \mathrm{Ca}$ at the Murodo-Daira site in 2009 and 2011 are 0.08 and 0.12 , respectively. These values are comparable to those in reference dust materials such as CJ1 (0.17), CJ-2 (0.06), and Gobi (0.09). Therefore, nss- $-\mathrm{Ca}^{2+}$ can be used as an indicator of mineral dust. High abundances of nss- $\mathrm{Ca}^{2+}$ in snowpack samples indicate that a strong outflow of dust particles from the Asian continent was involved with a heavy snow precipitation.

To investigate the effect of Asian dust on LMW monocarboxylic acids, we plotted major LMW monocarboxylic acids (i.e., formic plus acetic acids) against nss- $\mathrm{Ca}^{2+}$ using all the data points (Fig. 5). Concentrations of formic plus acetic acids were found to increase linearly with that of nss- $\mathrm{Ca}^{2+}(r=0.88)$. The air mass trajectories have passed over the Asian continent including North China and Mongolia (Fig. 3). Asian dust particles may be a carrier of formic and acetic acids via acid-base interaction, forming carboxylate salts, when the Asian dust activity maximizes in North China. The pathways of long-range transport and sources of formic and acetic acids will be discussed in the following Sects. 4.2 and 4.3 .

Average concentrations of formic and acetic acids and nss- $-\mathrm{Ca}^{2+}$ in 2009 are higher than those in 2011. This may be related to a strong influence of the Asian dust events, although the detailed records of the Asian dust events in North China are not available at this moment. 


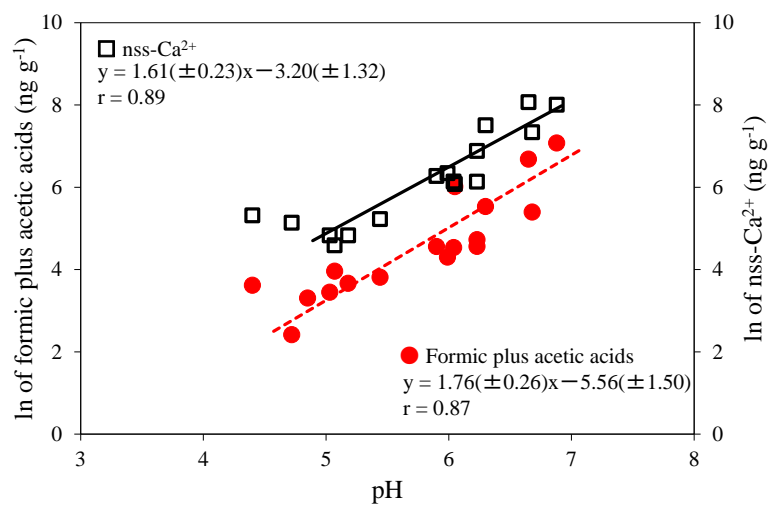

Figure 6. Scatter plots of the natural logarithm of formic plus acetic acids and $\mathrm{pH}$, and natural the logarithm of nss- $\mathrm{Ca}^{2+}$ and $\mathrm{pH}$. The solid and dotted lines represent the Deming linear regression.

\subsection{Long-range transport of formic and acetic acids and aerosol acidity/alkalinity}

Figure 5 presents the relationship between formic plus acetic acids and the $\mathrm{pH}$ of melt snow. Concentrations of formic plus acetic acids were found to increase exponentially with $\mathrm{pH}$ $(r=0.87)$. Interestingly, concentrations of nss- $-\mathrm{Ca}^{2+}$ were also found to increase exponentially with $\mathrm{pH}(r=0.89)$ (Fig. 6). Because LMW monocarboxylic acids have high vapor pressure (Saxena and Hildeman, 1996), they should be largely present as gases in the atmosphere (e.g., Kawamura et al., 1985; Liu et al., 2012). During long-range atmospheric transport, alkaline dust particles may be subjected to atmospheric titration by gaseous monocarboxylic acids.

We calculated ion balance in the snow pit at the MurodoDaira site near Mt. Tateyama. In this study, we could not use the data of a chloride ion $\left(\mathrm{Cl}^{-}\right)$because of the addition of $\mathrm{HgCl}_{2}$ into snow samples as bactericide. To calculate ion balance, we used equivalent ratios of $\mathrm{Cl}^{-}$to $\mathrm{Na}^{+}$ (1.26) obtained in the same snow pit in 2011 (Watanabe et al., 2012). Figure 7 shows total cations $\left(\mathrm{Na}^{+}, \mathrm{NH}_{4}^{+}, \mathrm{K}^{+}, \mathrm{Ca}^{2+}\right.$, and $\mathrm{Mg}^{2+}$ ) against total anions $\left(\mathrm{F}^{-}, \mathrm{MSA}^{-}, \mathrm{NO}_{3}^{-}, \mathrm{SO}_{4}^{2-}\right.$, and organic anions including normal $\left(\mathrm{C}_{1}-\mathrm{C}_{10}\right)$, branched chain $\left(\mathrm{iC}_{4}-\mathrm{iC}_{6}\right)$, aromatic (benzoic and toluic acid isomers), and hydroxyl (lactic and glycolic) monocarboxylic acids) $(r=0.95)$. The slope (1.26) of more than unity indicates that excess cations exist in the snow pit at the Murodo-Daira site near Mt. Tateyama, although $\mathrm{CO}_{3}^{-}$and $\mathrm{HCO}_{3}^{-}$, and unidentified organic anions were not taken into consideration.

We calculated the ratios of formic plus acetic acids / nss$\mathrm{Ca}^{2+}$ for the Murodo-Daira snow pit samples and compared the ratios of formic plus acetic acids / $\mathrm{nss}-\mathrm{Ca}^{2+}$ in the reference materials such as CJ-1, CJ-2, and Gobi. We found that formic plus acetic acids / $\mathrm{nss}-\mathrm{Ca}^{2+}$ ratios for the MurodoDaira snow pit samples (ave. 0.27) are significantly higher than those from CJ-1 (0.00036), CJ-2 (0.0012), and Gobi (0.0018) reference samples collected from the arid areas of

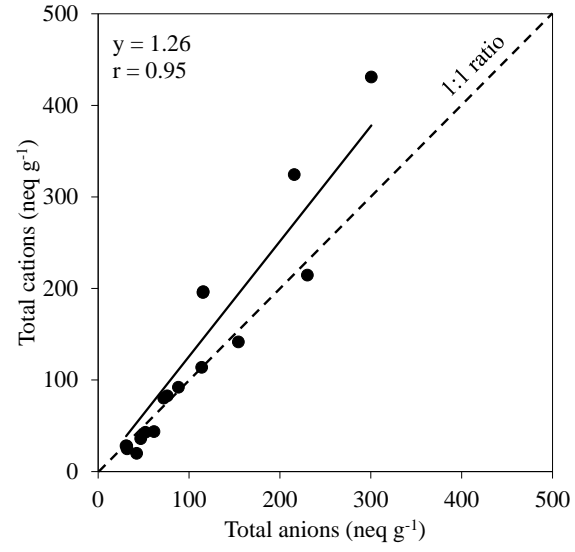

Figure 7. Linear regression plots between total cation equivalents (neq) and total anion equivalents (neq) in melt snow samples at the Murodo-Daira site near Mt. Tateyama.

North China. These results indicate that alkaline dust particles can adsorb gaseous MCAs in the atmosphere and largely control the long-range transport of LMW monocarboxylic acids from the Asian continent to the western North Pacific Rim. Based on a good correlation between monocarboxylic acids and nss- $\mathrm{Ca}^{2+}$, it is very likely that organic acids in aerosols exist in the form of salts such as $\mathrm{Ca}(\mathrm{HCOO})_{2}$, $\mathrm{Ca}(\mathrm{HCOO})\left(\mathrm{CH}_{3} \mathrm{COO}\right)$, and/or $\mathrm{Ca}\left(\mathrm{CH}_{3} \mathrm{COO}\right)_{2}$.

Prince et al. (2008) reported that gas-phase acetic acid is adsorbed on the surface of calcite $\left(\mathrm{CaCO}_{3}\right)$, a major mineral of dust particles. Acetic acid can form calcium acetate in the atmosphere (Alexander et al., 2015). Vapor pressures of those organic anions are significantly lower than those of free monocarboxylic acids. In addition, the lifetimes of formic and acetic acids with $\mathrm{OH}$ radicals are estimated to be 25 and 10 days, respectively, at $-13^{\circ} \mathrm{C}$ assuming the $\mathrm{OH}$ concentration of $1.0 \times 10^{6}$ molecules $\mathrm{cm}^{-3}$ (Paulot et al., 2011). This timescale is much longer than that of the atmospheric transport time of air mass from the Asian continent to Mt. Tateyama. Therefore, the acidity/alkalinity of an aerosol surface is an important factor in controlling the uptake of gaseous organic acids, and thus organic acid salts can be long-range transported as particles in the atmosphere from the Asian continent to the Japanese islands. Zhang et al. (2012) reported that $\mathrm{pH}$ of wet deposition for the last 2 decades showed a slight increase in the southeastern Tibetan Plateau, China, due to the presence of $\mathrm{Ca}^{2+}$ that is derived from Asian dust. We suggest that long-range atmospheric transport of LMW monocarboxylic acids associated with Asian dust over the Japanese islands would be changed in the future due to the changes in the emission of Asian dusts from the Asian continent that are associated with global warming and changes in land use (Zhang et al., 2003; Song et al., 2016). 

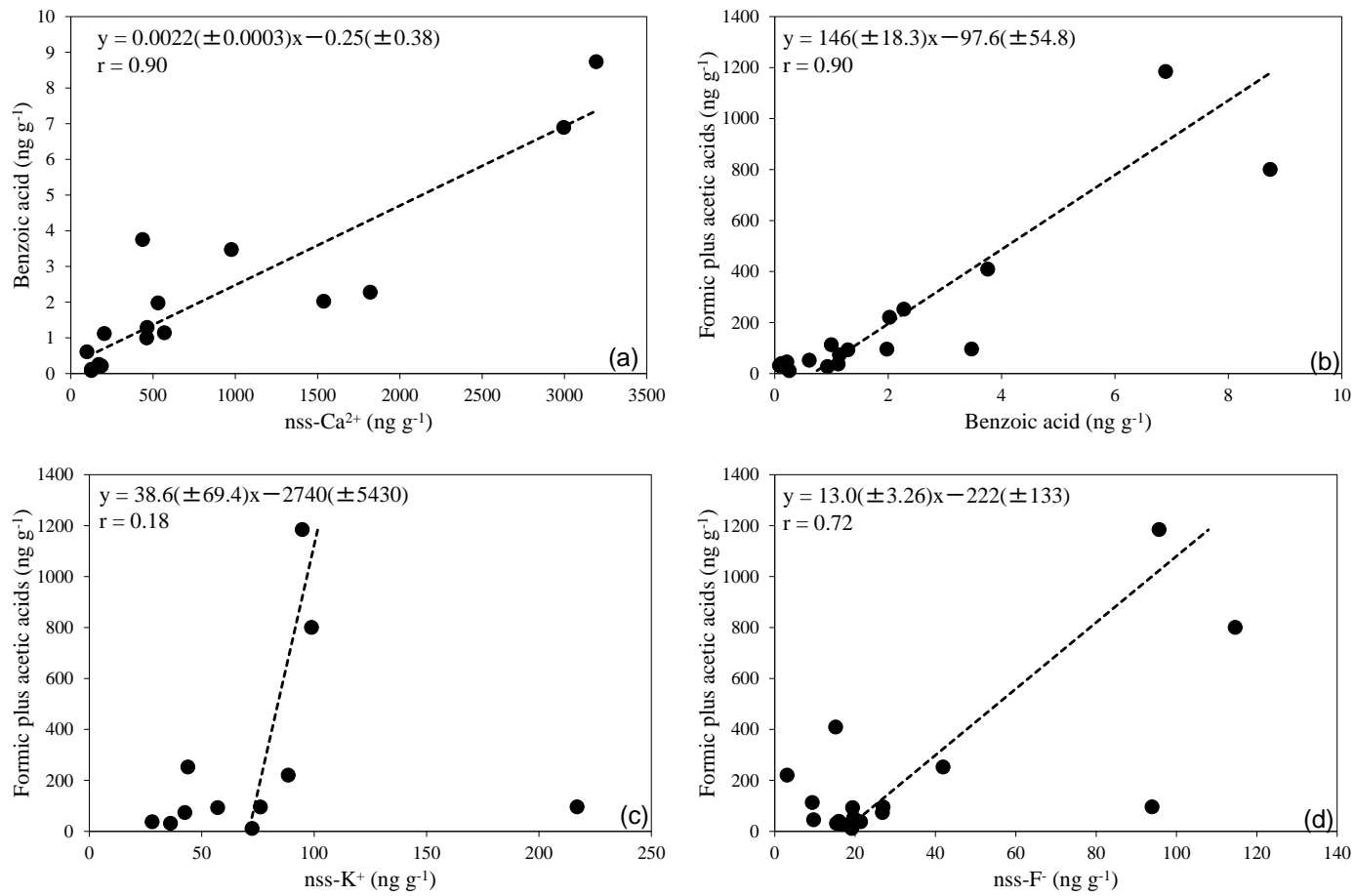

Figure 8. Scatter plots of (a) concentrations of benzoic acid vs. nss-Ca ${ }^{2+}$, (b) formic plus acetic acids vs. benzoic acid, (c) formic plus acetic acids vs. nss-K, and (d) formic plus acetic acids vs. nss- $\mathrm{F}^{-}$in Mt. Tateyama snow samples. The dotted line represents the Deming linear regression.

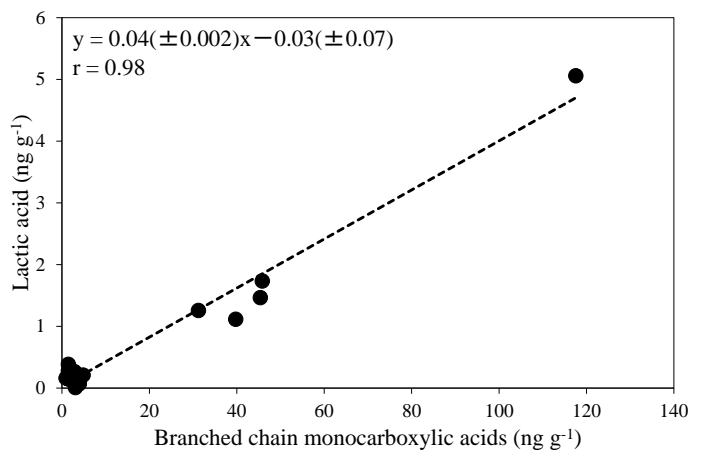

Figure 9. Scatter plot of concentrations of branched chain $\left(\mathrm{iC}_{4}-\right.$ $\mathrm{iC}_{6}$ ) monocarboxylic acids vs. lactic acid in Mt. Tateyama snow samples. The dotted line represents the Deming linear regression.

\subsection{Major contributions of anthropogenic monocarboxylic acids}

Benzoic acid is directly emitted from fossil fuel combustion (Kawamura et al., 1985) and also produced in the atmosphere by photo-oxidation of aromatic hydrocarbons such as toluene (Forstner et al., 1997), which are derived from human activities. Benzoic acid positively correlated with nss$\mathrm{Ca}^{2+}(r=0.90)$ (Fig. 8a). In addition, the average benzoic acid / nss- $-\mathrm{Ca}^{2+}$ ratio obtained for the Murodo-Daira snow pit samples $(0.0029)$ is $3-4$ orders of magnitude higher than those obtained from the Kosa reference materials such as CJ-1 (0.0000024), CJ-2 (0.0000033), and Gobi (0.0000078). Benzoic acid may also be adsorbed on the pre-existing particles via atmospheric titration of alkaline dust particles derived from the Asian continent. The air mass trajectories arriving at the Murodo-Daira site have passed over North China, where many industrial regions and mega-cities (e.g., Beijing) are located (Fig. 3).

Formic plus acetic acids showed a strong positive correlation with benzoic acid $(r=0.90)$ (Fig. 8b), indicating that they are derived from anthropogenic sources in the Asian continent. In contrast, nss- $\mathrm{K}^{+}$, a tracer of biomass burning (Zhu et al., 2015), did not show a positive correlation with formic plus acetic acids ( $r=0.18$ ) (Fig. 8c). nss- $\mathrm{F}^{-}$, a tracer of coal burning (Wang et al., 2005), shows a positive correlation with formic plus acetic acids $(r=0.72)$ (Fig. 8d); however, they were rather scattered. Biomass and coal burning is not a major source of monocarboxylic acids in the snow pit samples collected from the Murodo-Daira site near Mt. Tateyama. We consider that formic and acetic acids are both derived from anthropogenic and photochemical processes in the atmosphere of North China. They are adsorbed on the pre-existing alkaline Kosa particles via the atmospheric titration during a long-range atmospheric transport over the Japanese islands. 

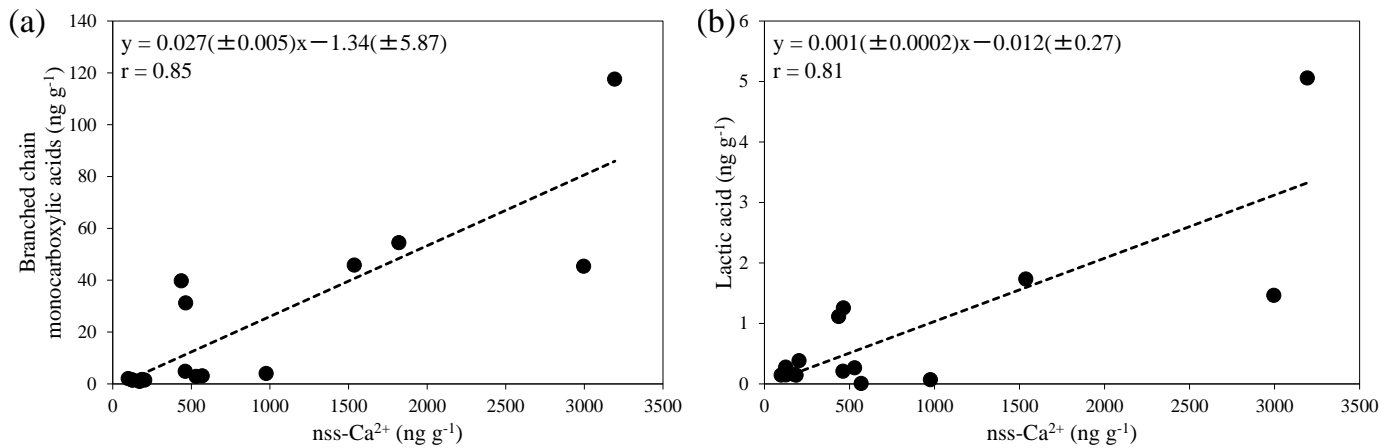

Figure 10. Scatter plots of (a) concentrations of branched chain $\left(\mathrm{iC}_{4}-\mathrm{iC}_{6}\right)$ monocarboxylic acids vs. nss-Ca ${ }^{2+}$ and (b) lactic acid vs. nss $-\mathrm{Ca}^{2+}$ in Mt. Tateyama snow samples. The dotted line represents the Deming linear regression.

The mean concentrations of formic and acetic acids in our samples in 2009 are higher than those reported in mountain snow samples from southern California (Kawamura et al., 1996), Tateyama (Kawamura et al., 2012) and the southern French Alps (Maupetit and Delmas, 1994), and ice core samples from Antarctica (de Angelis et al., 2012). The total MCA-C / DOC ratio (av. 21\%) in 2009 is significantly higher than those reported in rainwater samples from Los Angeles (4.4\%) (Kawamura et al., 2001), Shenzen, China $(2.3 \%)$ (Huang et al., 2010), and reference dust materials (CJ-1: 2.0\%; CJ-2: 2.9\%; and Gobi: 3.3\%). These results indicate that water-soluble LMW monocarboxylic acids in the snow pit samples near Mt. Tateyama constitute a significant fraction of water-soluble organic carbon, suggesting that entrainment of organic acids in alkaline dusts and snowflakes is significant during the atmospheric transport from China to Japan.

\subsection{Minor contributions of biogenic monocarboxylic acids}

Branched chain $\left(\mathrm{iC}_{4}-\mathrm{iC}_{6}\right)$ monocarboxylic acids are produced by bacterial activity of Bacteroides ruminicola, Megasphaera elsdenii, and Streptomyces avermitilis (e.g., Allison, 1978; Hafner et al., 1991). It is of interest to note that $\mathrm{iC}_{5}$ has not been reported in motor exhaust (Kawamura et al., 2000) and urban rainwater (Kawamura et al., 1996). Bacteria (lactobacillus) and plant tissues are known to produce lactic acid (Cabredo et al., 2009; Baker and El Saifi, 1953). Lactobacillus mainly exists in soil (Huysman and Verstraete, 1993). We found a strong positive correlation between branched chain $\left(\mathrm{iC}_{4}-\mathrm{iC}_{6}\right)$ acids and lactic acid $(r=0.98)$ (Fig. 9). This strong correlation suggests that these organic acids are closely linked in the biosynthetic processes associated with bacterial activity in soils.

Branched chain $\left(\mathrm{iC}_{4}-\mathrm{iC}_{6}\right)$ acids $(r=0.85)$ (Fig. 10a) and lactic acid $(r=0.81)$ (Fig. 10b) showed a positive correlation with nss-Ca ${ }^{2+}$. Maki et al. $(2011,2014)$ reported that bacterial communities are present in the layers of snow pit sequences at Murodo-Daira near the summit of Mt. Tateyama and are considered to be associated with Asian dust events. Bacterial species responsible for branched monocarboxylic and lactic acids have not been reported in the Tateyama snow samples at this time. However, our results suggest that branched chain monocarboxylic acids may be produced by bacterial process in soils of the Asian continent and transported over the Japanese islands with Asian dust. The contribution of biogenic monocarboxylic acids is much lower than anthropogenic monocarboxylic acids.

\section{Summary and conclusions}

Low molecular weight normal $\left(\mathrm{C}_{1}-\mathrm{C}_{10}\right)$, branched chain $\left(\mathrm{iC}_{4}-\mathrm{iC}_{6}\right)$, hydroxyl (lactic and glycolic), and aromatic (benzoic and toluic isomers) monocarboxylic acids were detected in the snow pit samples collected from MurodoDaira snowfield near the summit of Mt. Tateyama, central Japan. Acetic acid was detected as the dominant species $\left(125 \mathrm{ng} \mathrm{g}^{-1}\right)$, followed by formic acid $\left(85.7 \mathrm{ng} \mathrm{g}^{-1}\right)$ and isopentanoic acid $\left(20.0 \mathrm{ng} \mathrm{g}^{-1}\right)$. Enhanced concentrations of monocarboxylic acids and nss- $\mathrm{Ca}^{2+}$ were obtained in the snow pit samples with dust layers. We found that abundances of formic and acetic acids largely depend on non-sea-salt $\mathrm{Ca}^{2+}(r=0.88)$. These acids positively correlated with benzoic acid $(r=0.90)$ that is primarily produced by fossil fuel combustion and secondary photochemical oxidation of anthropogenic toluene and other aromatic hydrocarbons, indicating that monocarboxylic acids were mainly of anthropogenic and photochemical origin. Formic plus acetic acids exponentially correlated with $\mathrm{pH}(r=0.87)(\mathrm{pH}=4.7-6.9)$. Alkaline dust particles may be subjected to atmospheric titration by gaseous monocarboxylic acids.

In addition, we analyzed reference dust materials including Chinese loess samples from the Tengger and Gobi deserts for the measurements of LMW monocarboxylic acids and inorganic ions. The ratio of total monocarboxylic acid / nss$\mathrm{Ca}^{2+}$ at the Murodo-Daira snow pit samples (0.27) was found to be significantly ( 2 to 3 orders of magnitude) higher 
than those of Chinese loess reference samples (0.000360.0018). These comparisons suggest that gas-phase monocarboxylic acids are easily adsorbed on the surface of preexisting dust particles derived from the Asian continent to result in organic acid salts. Our study demonstrates that Asian dust is a key factor in promoting a long-range atmospheric transport of LMW monocarboxylic acids emitted and produced over North China to the western North Pacific Rim under a strong influence of the East Asian winter Monsoon. By forming the organic acid salts, LMW monocarboxylic acids can be more stabilized against the photochemical decomposition during long-range atmospheric transport.

\section{Data availability}

The data of this paper are available upon request to K. Kawamura (kkawamura@isc.chubu.ac.jp) or T. Mochizuki (tmochizuki@u-shizuoka-ken.ac.jp).

Acknowledgements. This study was in part supported by the Japan Society for the Promotion of Science (Grant-in-Aid nos. 1920405 and 24221001). We thank E. Tachibana for the support of ion and dissolved organic carbon measurements and the students and researchers of the University of Toyama for their help during the snow sampling. We also appreciate the helpful discussion with P. Q. Fu.

Edited by: R. Sullivan

Reviewed by: two anonymous referees

\section{References}

Alexander, J. M., Grassian, V. H., Young, M. A., and Kleiber, P. D.: Optical properties of selected components of mineral dust aerosol processed with organic acids and humic material, J. Geophys. Res., 120, 2437-2452, 2015.

Allison, M. J.: Production of branched-chain volatile fatty-acids by certain anaerobic bacteria, Appl. Environ. Microbiol., 35, 872877, 1978.

Andreae, M. O., Talbot, R. W., Andreae, T. W., and Harris, R. C.: Formic and acetic acid over the central Amazon region, Brazil, 1. Dry season, J. Geophys. Res., 93, 1616-1624, 1998.

Baker, J. and El Saifi, A. F.: Studies in the respiratory and carbohydrate metabolism of plant tissues, III. Experimental studies of the formation of carbon dioxide and of the changes in lactic acid and other products in potato tubers in air following anaerobic conditions, Philos. T. Roy. Soc. B, 140, 508-522, 1953.

Berg, W. W. Jr. and Winchester, J. M.: Aerosol chemistry of the marine atmosphere, in: Chemical Oceanography, edited by: Riley, J. P. and Chester, R., 2nd Edn., Academic Press, London, 173-231, 1978.

Cabredo, S., Parra, A., Saenz, C., and Anzano, J.: Bioaerosols chemometric characterization by laser-induced fluorescence: air sample analysis, Talanta, 77, 1837-1842, 2009.

de Angelis, M., Traversi, R., and Udisti, R.: Long-term trends of mono-carboxylic acids in Antarctica: comparison of changes in sources and transport process at the two EPICA deep drilling sites, Tellus B, 64, 17331, doi:10.3402/tellusb.v64i0.17331, 2012.

Duce, R. A., Arimoto, R., Ray, B. J., Unni, C. K., and Harder, P. J.: Atmospheric trace elements at Enewetak atoll: 1, concentrations, sources, and temporal variability, J. Geophys. Res., 88, 53215342, 1983.

Forstner, H. J. L., Flagan, R. C., and Seinfeld, J. H.: Secondary organic aerosol from the photooxidation of aromatic hydrocarbons: Molecular composition, Environ. Sci. Technol. 31, 1345-1358, 1997.

Hafner, E. W., Holley, B. W., Holdom, K. S., Lee, S. E., Wax, R. G., Beck, D., Mcarthur, H. A. I., and Wernau, W. C.: Branched-chain fatty acid requirement for avermectin production by a mutant of Streptomyces avermitilis lacking branched-chain 2-oxo acid dehydrogenase activity, J. Antibiot., 44, 349-356, 1991.

Huang, X. F., Li, X., He, L. Y., Feng, N., Hu, M., Niu, Y. W., and Zeng, L. W.: 5-year study of rainwater chemistry in a coastal mega-city in South China, Atmos. Res., 97, 185-193, 2010.

Huysman, F. and Verstraete, W.: Water-facilitated transport of bacteria in unsaturated soil columns: Influence of cell surface hydrophobicity and soil properties, Soil Biol. Biochem., 25, 83-90, 1993.

Iwasaka, Y., Minoura, H., and Nagaya, K.: The transport and special scale of Asian dust-storm clouds: a case study of the dust-storm event of April 1979, Tellus B, 35, 189-196, 1983.

Kanakidou, M., Seinfeld, J. H., Pandis, S. N., Barnes, I., Dentener, F. J., Facchini, M. C., Van Dingenen, R., Ervens, B., Nenes, A., Nielsen, C. J., Swietlicki, E., Putaud, J. P., Balkanski, Y., Fuzzi, S., Horth, J., Moortgat, G. K., Winterhalter, R., Myhre, C. E. L., Tsigaridis, K., Vignati, E., Stephanou, E. G., and Wilson, J.: Organic aerosol and global climate modelling: a review, Atmos. Chem. Phys., 5, 1053-1123, doi:10.5194/acp-5-1053-2005, 2005.

Kawamura, K. and Kaplan, I. R.: Capillary gas chromatography determination of volatile organic acids in rain and fog samples, Anal. Chem., 56, 1616-1620, 1984.

Kawamura, K., Ng, L. L., and Kaplan, I. R.: Determination of organic-acids $\left(\mathrm{C}_{1}-\mathrm{C}_{10}\right)$ in the atmosphere, motor exhausts, and engine oils, Environ. Sci. Technol., 19, 1082-1086, 1985.

Kawamura, K., Steinberg, S., and Kaplan, I. R.: Concentrations of monocarboxylic and dicarboxylic acids and aldehydes in southern California wet precipitations: comparison of urban and nonurban samples and compositional changes during scavenging, Atmos. Environ., 30, 1035-1052, 1996.

Kawamura, K., Steinberg, S., and Kaplan, I. R.: Homologous series of $\mathrm{C}_{1}-\mathrm{C}_{10}$ monocarboxylic acids and $\mathrm{C}_{1}-\mathrm{C}_{6}$ carbonyls in Los Angeles and motor vehicle exhausts, Atmos. Environ., 34, 41754191, 2000.

Kawamura, K., Steinberg, S., Ng, L., and Kaplan, I. R.: Wet deposition of low molecular weight mono- and di-carboxylic acids, aldehydes and inorganic species in Los Angeles, Atmos. Environ., 35, 3917-3926, 2001.

Kawamura, K., Matsumoto, K., Tachibana, E., and Aoki, K.: Low molecular weight $\left(\mathrm{C}_{1}-\mathrm{C}_{10}\right)$ monocarboxylic acids, dissolved organic carbon and major inorganic ions in alpine snow pit sequence from a high mountain site, central Japan, Atmos. Environ., 62, 272-280, 2012. 
Keene, W. C., Galloway, J. N., and Holden Jr., J. D.: Measurement of weak organic acidity in precipitation from remote areas of the world, J. Geophys. Res., 88, 5122-5130, 1983.

Keene, W. C., Mosher, B. W., Jacob, D. J., Munger, J. W., Talbot, R. W., Artz, R. S., Maben, J. R., Daube, B. C., and Galloway, J. N.: Carboxylic acids in clouds at a high-elevation forested site in central Virginia, USA, J. Geophys. Res., 100, 9345-9357, 1995.

Kesselmeier, J., Bode, K., Gerlach, C., and Jork, E. M.: Exchange of atmospheric formic and acetic acids with trees and crop plants under controlled chamber and purified air conditions, Atmos. Environ., 32, 1765-1775, 1998.

Legrand, M., Preunkert, S., and Jourdain, B.: Year-round records of gas and particulate formic and acetic acids in the boundary layer at Dumont d'Urville, coastal Antarctica, J. Geophys. Res., 109, D06313, doi:10.1029/2003JD003786, 2004.

Liu, J., Zhang, X., Parker, E. T., Veres, P. R., Roberts, J. M., de Gouw, J. A., Hayes, P. L., Jimenez, J. L., Murphy, J. G., Ellis, R. A., Huey, L. G., and Weber, R. J.: On the gas-particle partitioning of soluble organic aerosol in two urban atmospheres with contrasting emissions; 2 . Gas and particle phase formic acid, J. Geophys. Res., 117, D00V21, doi:10.1029/2012JD017912, 2012.

Maki, T., Aoki, K., Kobayashi, F., Kakikawa, M., Tobo, Y., Matsuki, A., Hasegawa, H., and Iwasaka, Y.: Characterization of halotolerant and oligotrophic bacterial communities in Asian desert dust (KOSA) bioaerosol accumulated in layers of snow on mount Tateyama, central Japan, Aerobiologia, 27, 277-290, 2011.

Maki, T., Puspitasari, F., Hara, K., Yamada, M., Kobayashi, F., Hasegawa, H., and Iwasaka, Y.: Variations in the structure of airborne bacterial communities in a downwind area during an Asian dust (Kosa) event, Sci. Total Environ., 488-489, 75-84, 2014.

Maupetit, F. and Delmas, J. D.: Carboxylic acids in high-elevation glacier snow, J. Geophys. Res., 99, 16491-16500, 1994.

Miyazaki, Y., Kawamura, K., and Sawano, M.: Size distributions and chemical characterization of water-soluble organic aerosols over the western North Pacific in summer, J. Geophys. Res., 115, D23210, doi:10.1029/2010JD014439, 2010.

Miyazaki, Y., Kawamura, K., Jung, J., Furutani, H., and Uematsu, M.: Latitudinal distributions of organic nitrogen and organic carbon in marine aerosols over the western North Pacific, Atmos. Chem. Phys., 11, 3037-3049, doi:10.5194/acp-11-3037-2011, 2011.

Miyazaki, Y., Sawano, M., and Kawamura, K.: Low-molecularweight hydroxyacids in marine atmospheric aerosol: evidence of a marine microbial origin, Biogeosciences, 11, 4407-4414, doi:10.5194/bg-11-4407-2014, 2014.

Mochizuki, T., Kawamura, K., and Aoki, K.: Water-soluble organic nitrogen in high mountain snow samples from central Japan, Aerosol Air Qual. Res., 16, 632-639, 2016.

Mori, I., Nishikawa, M., Quan, H., and Morita, M.: Estimation of the concentration and chemical composition of kosa aerosols at their origin, Atmos. Environ., 36, 4569-4575, 2002.

Nishikawa, M., Hao, Q., and Morita, M.: Preparation and evaluation of certified reference materials from Asian mineral dust, Global Environ. Res., 4, 103-113, 2000.

Nishikawa, M., Dashdondog, B., Ukachi, M., Onishi, K., Nagano, K., Mori, K., Matsui, I., and Sano, T.: Precipitation and chemical characterization of an Asian mineral dust certified reference material, Anal. Methods, 5, 4088-4095, 2013.
Osada, K., Iida, H., Kido, M., Matsunaga, K., and Iwasaka, Y.: Mineral dust layers in snow at mount Tateyama, central Japan: formation process and characteristics, Tellus B, 56, 382-392, 2004.

Paulot, F., Wunch, D., Crounse, J. D., Toon, G. C., Millet, D. B., DeCarlo, P. F., Vigouroux, C., Deutscher, N. M., González Abad, G., Notholt, J., Warneke, T., Hannigan, J. W., Warneke, C., de Gouw, J. A., Dunlea, E. J., De Mazière, M., Griffith, D. W. T., Bernath, P., Jimenez, J. L., and Wennberg, P. O.: Importance of secondary sources in the atmospheric budgets of formic and acetic acids, Atmos. Chem. Phys., 11, 1989-2013, doi:10.5194/acp-11-1989-2011, 2011.

Preunkert, S., Legrand, M., Jourdain, B., and DombrowskiEtchevers, I.: Acidic gases ( $\mathrm{HCOOH}, \mathrm{CH}_{3} \mathrm{COOH}, \mathrm{HNO}_{3}, \mathrm{HCL}$, and $\mathrm{SO}_{2}$ ) and related aerosol species at a high mountain Alpine site (4360 m elevation) in Europe, J. Geophys. Res., 112, D23S12, doi:10.1029/2006JD008225, 2007.

Prince, A. P., Kleiber, P. D., Grassian, V. H., and Young, M. A.: Reactive uptake of acetic acid on calcite and nitric acid reacted calcite aerosol in an environmental reaction chamber, Phys. Chem. Chem. Phys., 10, 142-152, 2008.

Saxena, P. and Hildemann, L. M.: Water-soluble organics in atmospheric particles: A critical review of the literature and application of thermodynamics to identify candidate compounds, J. Atmos. Chem., 24, 57-109, 1996.

Shimizu, A., Sugimoto, N., Matsui, I., Arao, K., Uno, I., Murayama, T., Kagawa, N., Aoki, K., Uchiyama, A., and Yamazaki, A.: Continuous observations of Asian dust and other aerosols by polarization lidars in China and Japan during ACE-Asia, J. Geophys. Res., 109, D19S17, doi:10.1029/2002JD003253, 2004.

Song, H., Zhang, K., Pian, S., and Wan, S.: Spatial and temporal variations of spring dust emissions in northern China over the last 30 years, Atmos. Environ., 126, 117-127, 2016.

Tsai, Y. I. and Chen, C. L.: Characterization of Asian dust storm and non-Asian dust storm $\mathrm{PM}_{2.5}$ aerosol in southern Taiwan, Atmos. Environ., 37, 2423-2427, 2006.

Wang, Y., Zhang, G., Tang, A., Yuan, H., Sun, Y., Chen, S., and Zheng, A.: The ion chemistry and the source of $\mathrm{PM}_{2.5}$ aerosol in Beijing, Atmos. Environ., 39, 3771-3784, 2005.

Watanabe, K., Nishimoto, D., Ishita, S., Eda, N., Uehara, Y., Takahashi, G., Kunori, N., Kawakami, T., Shimada, W., Aoki, K., and Kawada, K.: Formaldehyde and hydrogen peroxide concentrations in the snow cover at Murododaira, Mt. Tateyama Japan, Bull. Glaciol. Res., 30, 33-40, 2012.

Yang, X. Y., Yamada, M., Tang, N., Lin, J. M., Wang, W., Kameda, T., Toriba, A., and Hayakawa, K.: Long-range transport of fluoride in East Asia monitors at Noto Peninsula, Japan, Sci. Total Environ., 407, 4681-4686, 2009.

Zhang, N., He, Y., Cao, J., Ho, K., and Shen, Z.: Long-term trends in chemical composition of precipitation at Lijiang, southeast Tibetan Plateau, southwestern China, Atmos. Res., 106, 50-60, 2012.

Zhang, X. Y., Gong, S. L., Zhao, T. L., Arimoto, R., Wang, Y. Q., and Zhou, Z. J.: Sources of Asian dust and role of climate change versus desertification in Asian dust emission, Geophys. Res. Lett., 30, 2272, doi:10.1029/2003GL018206, 2003.

Zhu, C., Kawamura, K., and Kunwar, B.: Effect of biomass burning over the western North Pacific Rim: wintertime maxima of anhydrosugars in ambient aerosols from Okinawa, Atmos. Chem. Phys., 15, 1959-1973, doi:10.5194/acp-15-1959-2015, 2015. 